\title{
Barriers to Youth Literacy: Sociological and Canadian Insights
}

\author{
KATE TILLECZEK \\ University of Prince Edward Island \\ VALERIE CAMPBELL \\ University of Prince Edward Island
}

\begin{abstract}
This paper explores the barriers in youth literacy with qualitative interviews with 22 young people and 22 youth service providers from Prince Edward Island, Canada. It then compares these perspectives with a review of literatures on youth literacy. The paper outlines a sociological framework for the study of youth literacy that makes visible the complex cultural nests of youth within which becoming literate is negotiated. Rather than relying solely on individual literacy scores as the only measure of if and to what level young people are literate in contemporary society, the study addressed how barriers are encountered and negotiated. The findings show that barriers exist in multiple contexts in school, community and family and that they are not easily interpreted or predictable. Even high school completion does not guarantee literacy for some youth and both service providers and young people provide similar and disparate perspectives on barriers and possibilities for better support.
\end{abstract}

\section{Introduction}

. . . literacy for "youth-at-risk" is a specialized area of interest that has not yet received a large amount of focused research attention. To date youth literacy has been analyzed largely along a series of tangents: social and demographic, economic, interview-attitudinal and to some degree educational. At no point has the field been subject to a detailed research effort (Malcolmson, 2001, p. 2).

Despite the passage of 12 years since Malcolmson wrote the above words, little has changed. For instance, a more recent collection of work on adolescent literacy demonstrates that "more research [is] needed in adolescent literacy" (Christenbury, Bomer, \& Smagorinsky, 2009, p. 12). The authors further stated that, "sadly, ... we are not implementing in the schools and our communities what researchers, including those who study their own practice, have found and also what merits further implementation and investigation" (p. 12). 
This paper provides sociological insights on youth literacy that begin to bridge these gaps. We argue that being and becoming a literate young person in contemporary society is an increasingly critical but slippery process. It is critical because of the rhetorical push for youth to become increasingly literate and yet meanings and measurements of literacy are in flux. We concur that "in today's world, literacy comprises so many competencies that even getting a grip on the construct can be a slippery process" (Christenbury, Bomer, \& Smagorinsky, 2009, p. 5). In addition, there is very little sociological research that examines youth literacy from the point of view of young people themselves or that invites interrogation of the meaning of literacy or the way in which literacy is socially or culturally organized for youth. However, we do know that "the degree to which a person is considered literate, then, is not static, but is a judgment based on the local standards that follow from the ways in which particular cultures construe the purpose of using texts for communication and expression" (Christenbury, Bomer, \& Smagorinsky, 2009, p. 8).

Further, this paper provides evidence of important barriers in the literacy process as encountered by youth. For example, we have found that youth literacy is understudied, underfunded, and misunderstood especially as relates to young people who are continually marginalized in schools by socioeconomic, racial/ethnic, and cultural statuses. The largest breach is witnessed in the lives of youth failed by public education and left to acquire literacy skills through a vast fragmented system of disconnected social programs (Tilleczek \& Campbell, 2011). These young people are overlooked in most literature as they are difficult to find due to their living between or outside of social institutions that most often measure and define literacy such as schools, workplaces, and training centres (Tilleczek \& Campbell, 2011).

In this paper we argue for a sociological understanding of youth literacy to open a space for ongoing investigations into these barriers. The article is based on an exploratory study in the province of Prince Edward Island (PEI), Canada and designed to get beneath literacy scores and examine social processes. The review of literature is international in scope and holds lessons for those working in youth literacy research and practice. Guided by the early work of Fitzgerald (1998) we detail current and various meanings and social barriers to literacy in young lives from the perspectives of 22 young people and 22 adults who work in youth literacy services. They provide definitions and meanings of literacy arising from their own life experience. They assist in describing which young people struggle with literacy and how these struggles are socially encountered in the context of shifting concepts of youth literacy. For example, Malcolmson (2001) reports how literacy was once conceived as a simple dichotomy of reading and writing proficiency and has now evolved into a complex constellation of "skills" for young people.

... literacy is no longer just a question about being able to read, but is a more complex grouping of skills. The survey included a number of prose sections, such as texts from newspapers and brochures; an array of maps, schedules, charts and graphs to measure document literacy; and arithmetic operations to test basic 
quantitative literacy. These are the skills identified by experts as being necessary to survive and prosper in advanced industrialized countries. (OECD, 2000 cited in Malcolmson, 2001, p. 3)

Lewis and Del Valle (2009) argue for a definition beyond reading and writing and defined literacy as "the range of practices involved in the coding of socially and culturally relevant signs and symbols" (p. 309). Workplace skills and labour market knowledge are now also fundamental. The Association of Canadian Community Colleges (ACCC, 2003) expands their definition of literacy to incorporate skills necessary in seeking and maintaining employment. They combined the definition of essential skills used by Human Resources Development Canada (HRDC) with that of employability skills used by the Conference Board of Canada into essential employability skills which are,

the generic set of skills, attitudes, and behaviors that are necessary in any career area and which are essential to any person aiming to be successful in obtaining and progressing in his or her job. The essential employability skills are the foundation skills to a fulfilling personal and work life. These include literacy, numeracy, and document use, inter-personal and intrapersonal skills. (ACCC, 2003, p. 7)

This inclusive definition calls for provision of educational and economic opportunity for youth that crosses paths with intransigent and narrow ideas about literacy. While the move from merely functional to contextual definitions is apparent, so too is the addition of skills such as creativity and critical thinking. Malcolmson (2001) states that "an examination of promising practices in adolescent literacy amply demonstrates that it is precisely this aspect of quality literacy programming that can awaken interest in learning and creative expression amongst youth who have had negative experiences with schooling"(p. 6). And even those whose educational experiences may have been more positive appear to lack the necessary skills to carry over into post secondary education or the workforce (Beaufort, 2009).

We argue that youth literacy requires a sociological and strength-based approach that examines both risk and protective situations in youth education and employment. Youth literacy "shapes the core strategies by which adolescents learn to negotiate meaning and think critically about the texts in their lives, whether in the context of the school or the world outside of the school" (Vacca, 1998 cited in Malcolmson, 2001, p. 6). Yet "there is little or no attention being paid to the impact that reading and interpreting images and other representational modes beyond traditional print are having on youth and society at large" (Alvermann, 2009, p. 24). At the international level, the Organization for Economic and Community Development (OECD)'s Program for International Student Assessment (PISA), International Adult Literacy Survey (IALS), and Education and Income Statistics are relevant as they confirm the need to address literacy with Canadian youth. New PISA data demonstrates that $21 \%$ of youth in certain Canadian provinces fall below Level 2 (the level considered as the baseline level of proficiency by the 
OECD). The Canadian average below Level 2 is $10.3 \%$ (Knighton, Brochu, \& Gluszynski, 2010). A recent US policy paper suggests that if the US could boost its average PISA scores by 25 points over the next 20 years, it could lead to a gain of 41 trillion dollars in the US economy over the lifetime of the generation born in 2010 (Paine \& Schleicher, 2011).

It is not enough to know literacy scores are low; we must understand how and why this is so and what is happening to the young people who struggle to become literate. The OECD (2010) continues to demonstrate long-term trends in lower socioeconomic status relating to lower test scores. Willms (1999) has shown how these trends in literacy performance are echoed for Canadian youth. Using OECD's IALS and Canada's National Longitudinal Survey of Children and Youth (NLSCY) data, he demonstrates strong relationships between familial socio-economic status measures (parental education, income, and household income) and literacy skills. He shows how literacy skills can wane by grade 3 for those from lower socioeconomic families with the trends lasting through high school. He also demonstrates how 'schools matter' through their educational practices with a need to provide more literacy supports in middle schools. 'Communities also matter' according to Willms in that some local communities have lower economic and social capital, resulting in lower academic achievement.

At the national level, youth policy frameworks are being written which draw on meta-analyses relating to youth transitions and vulnerability (Bell \& Bezanson, 2006; Bell \& O'Reilly, 2008; Franke, 2010; Freiler, 2010). For instance, Willms (2009) released a set of papers from the Youth in Transition Study (YTS) and NLSCY defining how poverty, lower family income, lower parental education, disability, and minority or immigrant status continue to define vulnerable youth populations and lower scores in literacy. It is necessary to understand the social organizational roots of these literacy trends and how/when young people are most marginalized in the process of becoming literate.

\section{Theoretical Framework}

Complex cultural nesting (Tilleczek, 2011) is a sociological framework used to make visible the social organization, inequalities, and experiences of young lives. Youth activities are nested within a complex cultural network in and between schools, communities, and family. Young people face challenges and opportunities relating to literacy within and across interconnected spheres of home, school, work, and community and are inseparable from, and nested within cultures and contexts of literacy. For instance, youth live within societal definitions and measurements of what it means to be literate and they inhabit a public school system which is meant to teach and enhance literacy. In Canada, the public education system ranges from Kindergarten (typically age 5) to secondary school completion at grade 12. It is assumed that graduation from secondary school leaves youth with requisite literacy and numeracy skills to continue along a pathway into work or further post-secondary education in community college or university. Indeed, a number of provinces have standardized literacy tests administered in grade 10 (approximately 15 years of age) for which a pass is mandatory for school completion. We have indicated above, however, that many (21\%) young Canadians are, 
by the age of 15 years, still struggling with literacy skills as measured by PISA (Knighton et al., 2010).

Being a young person and becoming an adult is therefore the result of many social forces that entangle the daily lives of young people. A focus on the tensions in fundamental social processes of being, becoming, and belonging encapsulates identity negotiation and life story (Eccles et al., 1993; Tilleczek, 2011). In conjunction with their social class, minority group status, gender, and cultural experiences, young people identify along a continuum as literate citizen which is traversed on physical, cognitive, emotional, and social terrains (Lerner, 2006). Resources buffering ill effects for youth are a sense of autonomy, self-efficacy, competence, and confidence (Lord, Eccles, \& McCarthy, 1994). Becoming a literate citizen requires these resources. Both being literate and feeling competent are prerequisites for later employment and further education.

Indeed, low literacy levels are a crucial barrier to success in the workplace (Carroll, 2009; Chaulk, McQuaid, \& Smith, 2002; McKenna \& Penner, 2009; PEI Literacy Alliance, 2010). With a focus on knowledge-based industries, there has been a significant increase in jobs that require a post secondary degree and a decrease in jobs that require a high school diploma or less (McKenna \& Penner, 2009). Almost 50\% of PEI's working population has less than high school education (McKenna \& Penner, 2009) and those in the 16-25 age categories scored poorly in literacy assessments (Lees, 2006). These levels of education and literacy are in turn deemed "inadequate for the new economy" (Murphy, 2001). A rising number of part-time and contract jobs make it even more difficult for youth to become established in a career (Canadian Rural Partnership, 2007; Carroll, 2009; PEI Advisory Council on the Status of Women, 2010).

The complex cultural nesting theory makes visible these complex cultural nests of youth within which becoming literate is negotiated. Rather than relying solely on individual literacy scores as the only measure of if and to what level young people are literate in contemporary society, the study addressed how barriers are encountered and negotiated. This framework draws upon but moves past Bronfenbrenner's (1979) descriptive model of important social contexts and towards a deeper sociological analysis by which social contexts are politically, economically, and socially organized, traversed, understood, and negotiated. Invoking and adapting for youth a feminist sociology based upon Smith $(1984,1987,1990,2002)$ as “.... an inquiry intended to disclose how activities are organized and how they are articulated to the social relations of the larger social and economic process" (Smith, 1987, p.151), the framework grounds social analysis in everyday lives of young people. It also views "development" in a non-traditional sense in which time and life course (Elder, 1995, 1997) remain central but are instead conceived as non-linear, dynamic, biographies nested within complex societies (Furlong, Cartmel, Biggart, Sweeting, \& West, 2003; Tilleczek, 2011; Tilleczek et al., 2010). For example, personal biography and narrative are invoked to show how life's critical junctures are always embedded in social context and that young people make numerous non-linear shifts as they actively negotiate the contexts in which they live. They enjoy school and yet decide to leave it. They long to re-enter school but find it onerous. They excel one 
year at literature and in another, mathematics, or both. They make friends who both assist and hinder their lives. The nuance and fluidity in the life stories of youth (Tilleczek et al., 2010) makes it necessary to determine how and why young people actively live out their narratives and what they are up against in doing so (Pais, 2003).

Late modernity is further characterized by a weakening of social networks that traditionally supported young people (Beck, 1992) and transitions to adulthood are increasingly elongated and complicated (Furlong \& Cartmel, 2007; Tilleczek et al., 2010). Lifestyles have become individualized and problems such as illiteracy are still too often understood to be outcomes of individual failings, solved only through personal action. A key feature of modernity is this fallacy of individual control which obscures the social relations between people and institutions that govern them (Furlong \& Cartmel, 2007). It is therefore critical to examine social relations and everyday experiences of young people at the nexus of inquiry (Tilleczek, 2011).

\section{Research Processes}

In conjunction with this sociological view on youth literacy, we collected data that assisted us in making connections between the everyday lives of marginalized young people who are most often missed in literacy research. We attempted to interpret their stories and perspectives in relation to emerging contexts and trends arising from a critical reading of literature. The conceptual meta-synthesis ${ }^{1}$ of literature arose from published academic and grey $^{2}$ materials and began with local (provincial and community), then national (Canada), then international items ${ }^{3}$. Internet searches led to 102 sources: published, academic (peer reviewed) papers from various disciplines $(n=6)$; reviews of literature $(\mathrm{n}=2)$; policy documents $(\mathrm{n}=15)$; research reports (government, NGO, community, university/college) $(n=64)$; and other grey literatures (papers, presentations, news articles) $(n=15)$. The conceptual and critical meta-synthesis of the literature identified barriers to successful youth pathways.

The interviews allowed us to speak with a range of people who had experienced the phenomenon under study (Morse, 2000) and worked toward saturation of meanings and barriers in interviews with 44 key informants (22 service providers and 22 young people). These participants provided experiences and perspectives on the meanings of literacy and described the ways in which they encountered barriers to literacy. ${ }^{4}$ The main criterion for youth participants was age (18-27 years) so as to (a) cover the age range of the various definitions of 'youth' used in service and programming (the range is from 15 to 29 years); (b) address the age demonstrated as the largest gap in the literature; and c) speak to young people for whom parental consent was not necessary. The inclusion criteria for service providers were both front line and administrative roles from across three sectors: education (secondary school, post-secondary school, Department of Education), industry, and community agencies. To address the principle of sample variation both youth and service providers from various communities were identified through a snowball sampling technique. Service providers were from front-line $(n=15)$ and administrative $(n=7)$ positions and youth from rural $(n=13)$ and urban $(n=9)$ communities. Participants were interviewed at a mutually agreed upon site. Interviews 
lasted approximately 45-60 minutes and were audiotaped. A brief socio-demographic form was presented to record important demographic information: age, gender, position in the system, years of service in the system, cultural/ethnic identity, educational background, literacy level, and so forth. The interview ensued with a list of specific questions. Youth participants were provided with a $\$ 20$ honorarium for their participation.

Three analyses are provided in this paper: socio-demographics to describe the samples; the meanings of literacy arising from the interviews; and thematic analysis of the barriers to literacy (both from interviews and literature). Thematic analysis of the interview notes emerged as a process of progressive focusing, whereby understanding the research problem was refined and general barrier themes were considered (Hammersley \& Atkinson, 1995; Silverman, 1993). Two research team members read notes and intercoder disagreements (none were encountered in the analysis) were to have been resolved by returning to discuss original texts and audio files.

\section{Findings: From Literature}

Barriers to youth literacy in the literature fell into two categories: barriers to access or participation in programs; and barriers to success in programs. Barriers to participation are the practical or logistical considerations that permit youth to access opportunities that exist. Lack of money is one such barrier tied to socioeconomic status and poverty (Flanagan, 2009; McKenna \& Penner, 2009; Timmons, 2005; Watt, 2002). Although some programs such as Adult Education and GED preparation are tuition-free, the cost of transportation and childcare is prohibitive for those with low incomes. Low wages and seasonal employment exacerbate this challenge, particularly for those who require childcare (Flanagan, 2009). A certain complex spiral occurs for the young people who are uncertain or unable to follow their pathways to education and employment and then become less than confident about their abilities. Table 1 provides a synopsis of the barriers identified through the literature and organized at societal, work, school, home, and individual levels. The barriers intersect such that poverty or financial stress exacerbates individual daily struggles at school, home, or work. We used these barriers

as a starting point from which to read and interpret similarities and difference in the interviews.

Table 1 
Barriers in Youth Pathways from the Literature*

\begin{tabular}{|c|c|c|}
\hline Culture \& Society & Work, School, \& Home & Individuals \\
\hline Social class - poverty & $\begin{array}{l}\text { Early adult status (family } \\
\text { responsibilities related to }\end{array}$ & No transportation \\
\hline Minority status & socials class) & $\begin{array}{l}\text { Lack of Literacy and } \\
\text { Employability }\end{array}$ \\
\hline "Place" (rural) & $\begin{array}{l}\text { Lack of time to be in } \\
\text { education or training }\end{array}$ & Essential Skills \\
\hline Immigration/resettlement & & Lack of confidence \\
\hline $\begin{array}{l}\text { Labour market demand } \\
\text { (seasonal, }\end{array}$ & $\begin{array}{l}\text { Lack of career training or } \\
\text { information in high schools }\end{array}$ & $\begin{array}{l}\text { (self-esteem) in } \\
\text { pursuing further } \\
\text { education }\end{array}$ \\
\hline $\begin{array}{l}\text { underemployment, too few } \\
\text { jobs, new jobs demanding } \\
\text { more education) }\end{array}$ & $\begin{array}{l}\text { Lack of caring adults as } \\
\text { mentors or guides }\end{array}$ & $\begin{array}{l}\text { Lack of knowledge } \\
\text { about what/how to }\end{array}$ \\
\hline $\begin{array}{l}\text { Low value placed on youth } \\
\text { literacy / education and low }\end{array}$ & $\begin{array}{l}\text { Family literacy issues } \\
\text { and/or low value placed on } \\
\text { literacy / education }\end{array}$ & $\begin{array}{l}\text { pursue additional } \\
\text { education or training }\end{array}$ \\
\hline $\begin{array}{l}\text { Poor fit between youth } \\
\text { education experiences and } \\
\text { skills and the labour market } \\
\text { needs }\end{array}$ & $\begin{array}{l}\text { Public education at high } \\
\text { school level not necessarily } \\
\text { preparatory for work or } \\
\text { post-secondary success (ill } \\
\text { prepared for access or } \\
\text { success) }\end{array}$ & $\begin{array}{l}\text { Lack of motivation (if } \\
\text { already employed) }\end{array}$ \\
\hline \multicolumn{3}{|c|}{$\begin{array}{l}\text { *(Berringer, Penner, \& Sutton, 2007; Canadian Rural Partnership, 2007; Carroll, 2009; } \\
\text { Chaulk, McQuaid, \& Smith, 2002; Flanagan, 2009; Lees, 2006; Malcolmson, 2001; } \\
\text { McKenna \& Penner, 2009; Murphy, 2001; PEI Advisory Council on the Status of Women, } \\
\text { 2010; PEI Literacy Alliance, 2010; Timmons, 2005; Watt, 2002) }\end{array}$} \\
\hline
\end{tabular}

Findings: Sample Descriptions

Service providers $(\mathrm{n}=22)$ were mostly female $(\mathrm{n}=17)$ and ranged in age from 20 to 60 years with places of work reflecting variation. They represented 19 different programs across three sectors (education $(n=13)$, industry $(n=3)$, and community $(n=6)$ ); held a range of front-line $(\mathrm{n}=15)$ and administrative $(\mathrm{n}=7)$ positions; and ranged in their length of time in current positions from less than one year to 20 years. They all had high school diplomas, 13 had college diplomas, and six had university degrees.

Of the 22 youth participants, 13 were male and nine were female. Most lived in a rural community $(\mathrm{n}=13)$ with nine living in a city. They ranged in age from 18 to 27 
years with nine in the 18-20 range and 12 in the 21-27 range (one did not provide age; mean age of the 21 provided $=21.6$ years). The majority was living with someone other than their parents $(n=12)$ while eight lived at home and two lived alone. Three considered themselves to be homeless but were currently in a shelter or with friends. Only six were employed at the time of the interview and five others were in a training program. Eight of the young people had graduated from high school (two of them had a GED) and 10 had not yet graduated from high school. Most $(n=16)$ had attended one of the 10 provincial English high schools but four had never entered senior high school. Seven of these young people had been involved in academic upgrading and six reported having been identified with a special educational need in high school. Almost all reported familial support and encouragement for education $(n=20)$ while only 12 reported consistent teacher support and encouragement.

\section{Findings: Meanings of Literacy}

'You can understand what is read and express yourself articulately in writing' $(\text { Tyler })^{5}$

'Spelling...Speaking, anything to do with speech and, I guess, words in general.' (Dawn)

These young participants reflected on the meanings of literacy and the part that it has played in their lives. Many found it 'hard to define' but responded to a definition read by the interviewer. In each case, they suggested that literacy was related to 'getting through everyday things' and the 'ability to read and write and use it'. Some added spelling and public speaking or communication to the list. Only a couple of young people mentioned computer or technical literacy skills.

'That you can read and write and all of that...basically schooling' (Arnold)

'The ability to read and write and interpret the meaning behind the reading' (Mitchell)

Literacy was positioned as very important such that without it, young people have trouble applying for jobs, filling in applications, holding down work, communicating with others, or continuing education. Over half of these young people, even those who felt themselves to be literate, mentioned that they had some level of difficulty completing job applications. Those who had graduated from high school spoke about how their diploma did not necessarily ensure that they felt literate and how after graduation education opportunities were numerous but work opportunities minimal. These same young people wished that high school (especially English class) had been "more difficult" and "had higher standards". Many of the young people who had left school early also felt that they were literate in reading and they read often for pleasure or to learn something. However, they felt that spoken, written, and technical communication was 
lacking. Problems with literacy were linked with pathways to education and employment and many young people were living the connections between reading, work, and life pathways.

'I can manage but sometimes I struggle with it . . fillin' out the applications or whatever' (Luke)

Service providers also spoke about post-high school graduation literacy challenges for young people and relatively low levels of literacy in the province. They were concerned about high school graduates who are still functioning below standards and 'setting them up for failure' as they do not necessarily possess the basic skills needed for post-secondary school or work. An alternate worry was for those young people who have demonstrated ability but have had negative experiences in school with literacy which carry over in life. Those who have left school early have even greater barriers to face, specifically the cohort now in their late twenties. It was suggested that the changing workforce and skills were further complicating an already difficult situation.

'I think the ability to cope with whatever is happening to people, primarily in the workplace... I find that it is assumed that people can operate and perform at the tasks that they're working with, the problems arise when something new comes along and they either have to cope with that or they need to do some upgrading or they need to do workshops and so on; that's when the weaknesses in their ability to perform come through' (Donny)

'There are those who are able to fake it but are kind of stuck in those, I mean they're not menial jobs but they're jobs where there's no advancement, that require very little, you know, literacy skills or very little comprehension and they're able just, they've been able to adapt the skills over their lifetime of watching and learning and you know, just being able to say 'yeah, I understand' when they really don't and because they don't have the skills they're going from one job to another to another to another to another, they're losing jobs, they're losing confidence in themselves and their abilities and it's just kind of a downward spiral to the fact where they have no confidence in themselves at all and their abilities to do anything' (Leslie)

Meanings of literacy were consistent for administrators and front line workers with most addressing 'agility in the world' as relating to an ongoing continuum of abilities in 'what one needs to function in the world'. The range of skills and abilities mentioned was similar but more numerous than those mentioned by the young people. Of note is that which reflects a more ecological and everyday definition of what it means for youth to be literate. This well reflects the trend noted in the literature.

'Literacy is, I guess, the vocabulary that one needs to function in our world or our society and that can be literacy in a number of ways, it's not, I guess, a lot of 
people when I hear them talk about literacy, they talk about literacy as it applies to reading but I see literacy being much broader than that, everything from reading and writing to financial literacy, and some of those other... what we would normally have called more life skills, but the ability to have the tools to manage your life. Those are all a form of literacy because if you don't have them it's very difficult to function in your world and to have success.' (Erin)

All service providers spoke about the critical place of literacy in the lives of young people. Most spoke about needing to assist young people to understand this great impact on education and employment. Many reflected on the positive changes at the provincial and school levels with greater attention to reading and writing skills and having young people stay in school to graduation.

'I think that they have some of that basic foundation, and I think it's getting better, I will clarify that, with some of the emphasis on literacy. But I think literacy as it relates to reading and writing is primarily where this province has had its focus. I think young people today haven't been able to apply that learning to real life situations enough that it would mean it would be successful or that it would create much broader or more opportunities for them in terms of what they could do with that literacy and that learning.' (Erin)

\section{Findings: Barriers to Literacy}

'There is [sic] programs out there, but if you don't know about them, or if you don't know somebody that went to it or done [sic] it, for me I found it was kind of difficult cause like for a while I needed to do something, and I wanted to do something but I didn't know what and I didn't know what was out there and I didn't know there was funding and I didn't know I'd qualify and things like that.' (Inez)

This young person illustrates the complex interaction resonating in many interviews with young people barred both access and success in education or employment. Without education, literacy falters and affects employment and even high school education does not guarantee full literacy or success in either. Youth cited barriers to literacy in four constellations: self/friends, family, school, and work; these are summarized in Table 2 below. Overriding these were uncertain career goals and lack of money, regardless of whether they had completed high school. Many young people 'felt stuck' and could not find a way forward. Some 'aged out' such that services were no longer fitting and many did not want to return to high school. Often they did not know where to turn, had no knowledge of programs to assist, and were blocked by financial, familial, or practical circumstances. 
I heard [the program] was for youth and I'm getting too old to be hanging around those types of kids any more. [Interviewer- How old are you?] [Participant] 20.' (Gordon)

When they could access help (GED, training program, etc.) they did not always have the skills or support to succeed. Poverty related to the need to leave school to support family or in feeling excluded in school by other students. The sense of exclusion or 'being on the outside' in turn affected school experiences and literacy outcomes. Without question, school is important but also an impediment such that teachers, guidance counselors, and school structures/cultures created real problems for engagement in learning and literacy. Some even suggested that high school 'is a horrible environment for a young person to be exposed to.'

'I don't think they [school teachers/counselors] really knew what was going on . . - when I did go to school I just did my work like I was supposed to and went along with things.' (Inez)

'School always felt to me less about learning than about to see how much of this information you can retain until you have to write the test - it just never worked for me that way.' (Mitchell)

Specifically, youth participants spoke about not ever seeing or speaking with a guidance counselor. Others felt that they were socially excluded from school due to their social class position and not being able to afford the kinds of material things that other students could afford, leaving them on 'the outside'. Others were struggling academically and when they decided to leave, had no one at school to convince them otherwise. In fact, in a number of instances, they were told that this was a 'good idea'. Still others felt that they were not challenged in academic realms, even though they enjoyed school and were doing well.

'Looking back, like I wish there would have been a teacher or, you know, just an official at the school or whatnot to see, see that I was struggling and kind of, kind of catch that before it spirals, so to speak. And just for there to be more, like, seminars in the classroom and, you know, university graduates come in and speak about the importance of finishing high school.' (Mary)

Youth who had graduated from high school but did not continue into post secondary education did not have funds/time to pursue further education nor always have a clear and specific work goal. They expressed an unwillingness to spend their time and money, or accumulate debt, on education until they were clear on what they want to do. Another prevailing attitude was that they were literate enough to get by in life, or as one participant put it, 'OK with being average or good'. 
I don't want to get in there, spend all of my money, then realize that's not what I want to do for the rest of my life.' (Fred)

Awareness of available and/or active programs for youth was limited. Even front line service providers did not always know what was being done outside their particular geographical region or area of interest. There is no 'one stop shopping' place for youth who are struggling either to upgrade their education/literacy skills or find meaningful employment.

'When I go looking for stuff like this, career development thing or something like that I don't know who to speak to and I don't know who to ask who to speak to and I either get frustrated and feel like I am wasting my time or I get sent to the wrong person and go about it in a completely wrong direction, feel like I'm too rushed into something I don't know about and I usually just stop altogether and go collect myself..and end up going to talk to the exact same people a couple of weeks later.' (Mitchell)

The barriers to employment centered on availability, particularly in rural areas. Other barriers included lack of high school diploma or post secondary education, frequent job changes (a history of quitting), lack of job search skills and/or awareness of employment programs, and, for one participant, a criminal record. In addition, most of these young people experienced job applications and government forms roadblocks. Between being unable to understand the forms and the inability to technically fill them out, young people were blocked from training or employment opportunities. The form was standing between them and employment. 'I usually get two [application] forms just in case .. I'll fill one out and someone will correct my mistakes ... and then I'll write it again' (Dawn). Young people did not speak about many barriers at the level of the community except for the odd mention of difficulty of living in a rural community. There was also some mention that it was difficult to be accepted and find work if you did not know someone such that 'you get jobs through connections.' Table 2 presents a summary of the main thematic barriers from the perspectives of youth participants. Those in bold text indicate those that were also noted in service provider interviews. The table and quotes illustrate a complex spiral that is entered into for these young people. For some, addictions and/or mental health challenges figured prominently. Most of the young people were also reflective about the problems of being 'young'.

'Young people especially, younger than myself, have to really think about what they need more than about what they want at one particular time. That basically applies to everything. You can't just take a quick reward, you gotta think about things for the long run because you got a lot more life than the next five minutes.' (Mitchell) 
'I wasn't looking at my education as something I would need for the rest of my life... [I am] making the effort to look after things that I chose to ignore in the past.' (Mary)

'Every youth is different and has different needs...some youth don't need help and some youth do and some need help in different areas and some don't know what they need help with.' (Tyler)

Table 2

Barriers from Youth Interviews

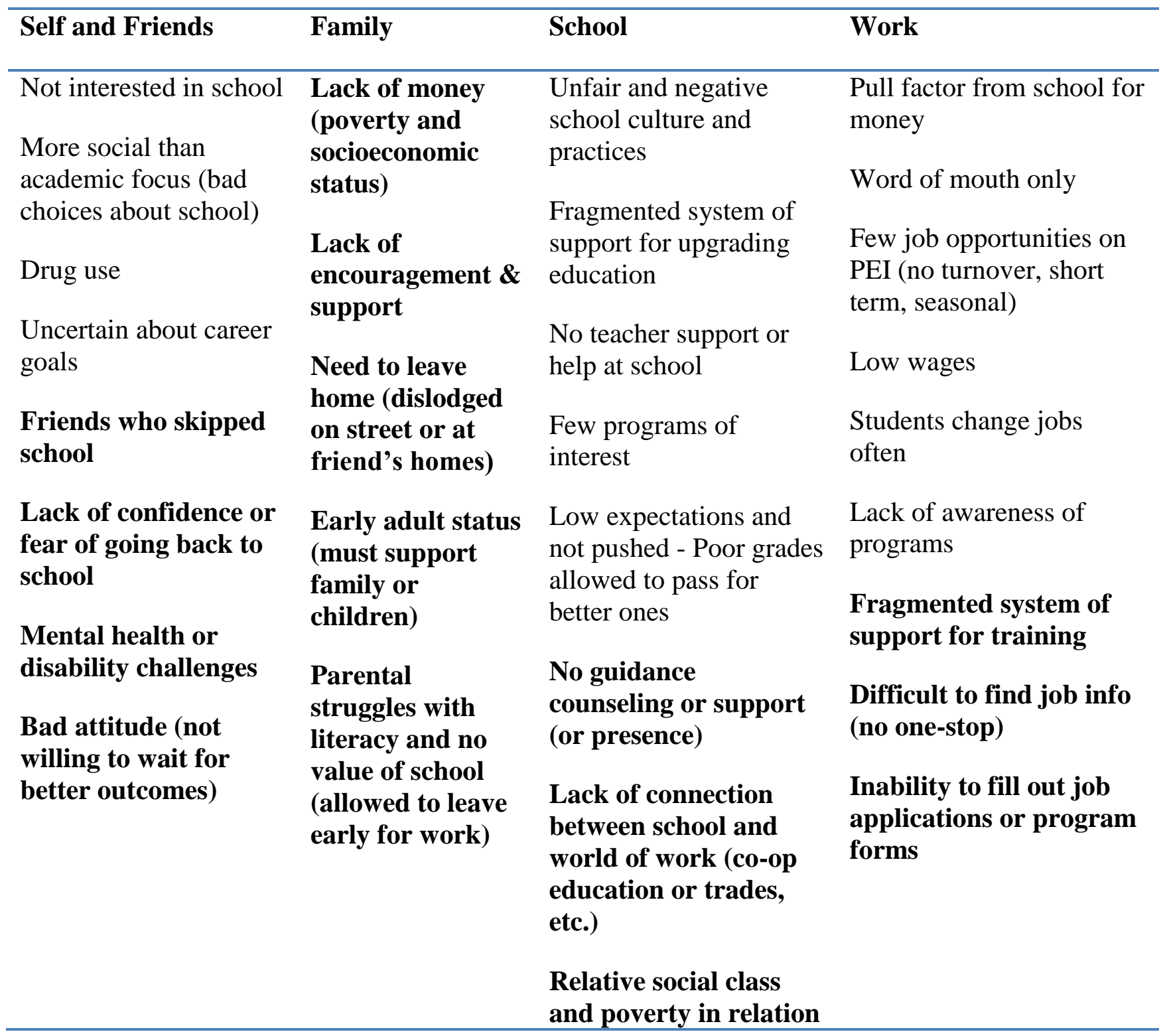




\section{to others (was \\ excluded, bullied)}

Poor grades not

remediated

For service providers, low socio-economic status and/or poverty was a very significant barrier and they spoke about the numerous ways in which schools and communities were not able to mediate the ongoing ill effects for young people. Mental health and addictions challenges also figured prominently in the list of challenges. Many mentioned other barriers at the individual level such that some young people 'don't want to ask for help' because of the stigma and stereotypes that marginalized young people face in making it through school and finding work (e.g., trades not considered valuable, stigmatized for seeking help, made fun of for being poor).

'Some of them have kind of gotten lost along the way.' (Leslie)

'I don't know that there are actual ways for [young] people to get the help they need, . . if someone is outside of school - you know there are people who have their grade 12 and they don't necessarily have the skills that they need. Where do they go? What do they do? Do they even understand why they don't have the skills they need? ...' (Sylvia)

Many service providers spoke about a need to re-engage parents, teachers, and others adults in the care and support of children as they become young adults. Service providers also recognized a complex spiral of decline that can take place across contexts.

'Youth are living adult lives now.' (Jill)

'The most significant barrier of all is poverty. If a young person, if a child enters school from a household where there is very little in the way of resources, . . . then that child is immediately faced by other children who can do better, who know more. And I think it doesn't take very long for such a child to begin to think that he or she is stupid. Once that's happened I think it becomes extremely difficult to get away from it.' (Mae)

'It's my experience that it's [the workplace] changing all the time, people are being asked to take on more things, more jobs, more responsibility. I think particularly as they just get older and they work their way through the system, it is sort of fairly normal for them to advance through the system. But the trouble is that they get themselves into a position where they realize that they can't cope, they can't handle the communication needs, they can't handle the technology needs that are an integral part of the job that's there.' (Donny) 
Gaps and barriers in public education were most often cited and were perceived to include a lack of career counseling in high school making it difficult for students to develop career goals or create a plan beyond high school. Guidance counselors and other school personnel spoke about the scope of their practice enlarging into mental health and daily life skills or 'whatever a student identifies as a need'. Many concluded that young people are leaving high school, either with or without a diploma, and not being literate or not knowing what to do.

'Are we setting those students up to fail at post secondary levels because they don't have those basic things they need to be successful?' (Erin)

'I think that the education system needs a whole good overhaul.' (Jill)

'Students don't know most of the time when they leave high school, what it is they want to do. Not just what they want to do, what they want to continue learning. They, they don't even have a good idea of who they are themselves.' (Erin)

Among the more interesting ideas was a critique of the ways in which adults are in power positions over young people and do not give them enough space to 'let us know what THEY know'. A lack of learning or literacy culture was mentioned as an influence on young people that may lead them to strive for less and/or settle for lower aspirations. Many noted the general lack of employment opportunities for youth and there are limited programs even for those who know about and access them. The heterogeneity of youth is recognized by some, but not all, in the helping services.

'It's kind of a hit and miss. Sometimes they're getting lost in the [education] system and the system doesn't want them around anymore. Sometimes the system wants to work with them.' (Leslie)'

you know what you want to put in it [a program] and the coordinators just go in an follow it and make changes as need be, because every group is different.' (Yvette)

Administrators noted the daunting challenges of applying for funding for services and programs that could enhance youth literacy. Service providers spoke about the "yoyo' programs that are short-term, hit and miss, and retractable. They also spoke about the inability of programs to make lasting impressions after young people have entered a spiral of decline. This perspective reiterates the literature such that there are programs available, but access, support, and success can be fleeting for young people.

The youth outreach isn't out there anymore and that's unfortunate, very. . . . because we could send our students there, the youth ones, and they could be in our classroom within a week and it was taking anywhere from 4-6 [using other services]" (Brenda) 
One of the barriers outlined by most service providers was the need for general system changes towards collaboration and connection across sectors (schools, community, and employment). 'If we're all working for the same reason for this kid, we all need to be, have all the same information' (Cherise). Table 3 summarizes the range of barriers reported by service providers (both front-line and administrators) with those in bold text denoting similarities with youth responses.

Table 3

Barriers from Service Provider Interviews

\begin{tabular}{|c|c|c|c|}
\hline Self and Friends & Family & School & Work \\
\hline $\begin{array}{l}\text { Low levels of youth } \\
\text { literacy (even high school } \\
\text { graduates) }\end{array}$ & $\begin{array}{l}\text { Parents own } \\
\text { negative experiences } \\
\text { with schools }\end{array}$ & $\begin{array}{l}\text { Credit for work outside of } \\
\text { school }\end{array}$ & $\begin{array}{l}\text { Limited place in bridge } \\
\text { programs for youth }\end{array}$ \\
\hline Unable to see the future & Family dissolution & $\begin{array}{l}\text { No support for } \\
\text { differentiated learning }\end{array}$ & $\begin{array}{l}\text { Haven't had or taken } \\
\text { opportunity to explore world } \\
\text { of work }\end{array}$ \\
\hline $\begin{array}{l}\text { Youth have unrealistic } \\
\text { expectations and are } \\
\text { looking for the "easy }\end{array}$ & $\begin{array}{l}\text { Lack of money } \\
\text { (poverty) }\end{array}$ & $\begin{array}{l}\text { Poor pedagogy-not } \\
\text { engaging or challenging }\end{array}$ & $\begin{array}{l}\text { Difficult for young people to } \\
\text { get experience - not enough }\end{array}$ \\
\hline way" & $\begin{array}{l}\text { Lack of } \\
\text { encouragement \& }\end{array}$ & $\begin{array}{l}\text { Lack of emphasis on } \\
\text { literacy and basic skills }\end{array}$ & $\begin{array}{l}\text { programs to provide } \\
\text { experience while in school }\end{array}$ \\
\hline $\begin{array}{l}\text { Friends and negative } \\
\text { peer pressures }\end{array}$ & $\begin{array}{l}\text { support (either do } \\
\text { too little or too } \\
\text { much for kids) }\end{array}$ & $\begin{array}{l}\text { (reading, writing) too } \\
\text { much technology in its } \\
\text { place }\end{array}$ & $\begin{array}{l}\text { Workplace changing -more } \\
\text { emphasis on technology }\end{array}$ \\
\hline $\begin{array}{l}\text { "Bad attitude" of youth } \\
\text { - want all to come easily } \\
\text { to them and do not } \\
\text { know where/how to look }\end{array}$ & $\begin{array}{l}\text { Does not value } \\
\text { education }\end{array}$ & $\begin{array}{l}\text { Does not prepare youth for } \\
\text { higher education }\end{array}$ & $\begin{array}{l}\text { Pre-employment screening } \\
\text { tests }\end{array}$ \\
\hline $\begin{array}{l}\text { for the help that is there } \\
\text { for them }\end{array}$ & $\begin{array}{l}\text { Parents struggle } \\
\text { with literacy }\end{array}$ & $\begin{array}{l}\text { Does not prepare youth for } \\
\text { work }\end{array}$ & $\begin{array}{l}\text { Lack of access to many } \\
\text { programs in rural areas } \\
\text { (education and employment) }\end{array}$ \\
\hline $\begin{array}{l}\text { Lack of confidence or } \\
\text { fear of going back to } \\
\text { school }\end{array}$ & $\begin{array}{l}\text { Youth leaving } \\
\text { home to escape }\end{array}$ & $\begin{array}{l}\text { Transition to high school } \\
\text { slippage point }\end{array}$ & $\begin{array}{l}\text { Inability to fill out job } \\
\text { applications or program }\end{array}$ \\
\hline $\begin{array}{l}\text { Mental health, } \\
\text { addictions, or disability } \\
\text { challenges }\end{array}$ & $\begin{array}{l}\text { Early adult status } \\
\text { (youth taking care } \\
\text { of siblings etc) }\end{array}$ & $\begin{array}{l}\text { Not flexible or open if } \\
\text { students need another } \\
\text { chance } \\
\text { Need support for students } \\
\text { "in the middle" } \\
\text { academically }\end{array}$ & $\begin{array}{l}\text { forms } \\
\text { Services scattered - hard } \\
\text { to find, especially if youth } \\
\text { don't know which service } \\
\text { they actually need }\end{array}$ \\
\hline & & School rules do not make & No one-stop for youth \\
\hline
\end{tabular}


sense to students

Class sizes too large

Streaming and stigma of streams not good for students

Need youth workers in schools

Public education not keeping pace with social change (not able to mediate problems for youth from poverty)

\section{No guidance counseling} or support

\section{Lack of application to world (co-op programs needed)}

\section{Poor grades never} remediated

\section{Discussion}

This paper considers and provides evidence of multiple barriers in youth literacy as an understudied and misunderstood set of complex experiences for youth. Literacy remains elusive for too many young people at precisely the time of societal insistence of its growing importance. This study has assisted in getting behind the singular measures of who is literate at any one point in time to examine instead the barriers faced and spirals of decline entered. Especially for youth continually marginalized in schools by social, economic, and cultural statuses, the barriers are deeply felt. The largest contravention in youth literacy is made clear in the tangle of barriers faced by those who have been failed by public education and left to acquire literacy skills through a fragmented system of disconnected social programs (Tilleczek \& Campbell, 2011). This begs an important set of future sociological research studies as to how and why this is so for young lives over time. This paper begins to examine how public education and youth literacy service systems must redress youth literacy and how these failures are socially organized in the complex cultural nests of young lives.

The young people and service providers have begun to expose these fissures and illustrate barriers at many levels. Their perspectives animate the literature and provide a 
window into youth literacy where scholarship and practice remain largely divided. For example, similar to Malcolmson (2001), these participants agreed that youth literacy holds complex and shifting meanings and skill groupings. The youth participants echo the importance of literacy skills as "necessary to survive and prosper in advanced industrialized countries" (OECD, 2000 cited in Malcolmson, 2001, p. 3). These participants also made visible the ways in which individual, school, and community influences and negotiations are required to become literate, especially when living in situations of lower socioeconomic or cultural status as outlined in the literature (Flanagan, 2009; McKenna \& Penner, 2009; Timmons, 2005; Watt, 2002; Willms, 1999; 2009).

Indeed, a complex spiral can be discerned for some young people who are barred access and/or success in either education or employment. Without education, literacy falters and affects employment and has long-term consequences. Even successful high school education did not guarantee full literacy for these youth. Many of these young people and service providers spoke about the ways in which graduating from high school does not necessarily make them feel or function as literate or ready for further education or work. While literacy is most often measured as a singular score that stamps young people as literate or not, this study suggests that a complex human social interaction takes place between young people, educators, families, and youth service providers. Promises are made, broken and negotiated and barriers are lived.

These barriers in youth literacy demand debate about why all youth struggling with literacy are not necessarily and simply 'at-risk'. They are demonstrating potential for resilience (Unger, 2004), and living more fluidly in and out of situation that put them at risk, in schools, communities, and families (Tilleczek et al., 2010) as they attempt to negotiate the fragmented system. Youth literacy research could move past pathological individual foci on singular measurement which reports only the trends. We must also provide critiques of these scores, learn why they remain low for certain groups of youth, and understand the meanings they hold. The barriers portrayed here invoke the work of Fine and Weis (1996, p. 270) who suggest that 'simple stories of discrimination and victimization, with no evidence of resilience or agency, are seriously flawed and deceptively partial, and they deny the rich subjectivities of persons surviving amid horrific social circumstances'. Attempts at gathering youth literacy stories may also generate narratives of 'hope and possibility' (Smyth \& Hattam, 2001, p. 412) that seldom emerge from pathological analyses.

The literature and interviews presented here demonstrate the need for continued study of youth literacy that gets at the root of the barriers. These barriers confine many young people to a less than literate existence at the very instant that society calls upon them to become a more educated and literate " 21 st Century" generation. The anxiety around youth literacy is palpable for youth and adults alike. This youth literacy paradox requires ongoing sociological examination with, for, and by young people into the place, meaning, and measure of literacy in modern young lives. 
${ }^{1}$ Systematic review techniques are used in qualitative research to access as many relevant documents as possible (see Evans, 2002) and findings are subject to a meta-synthesis which refers to the conceptual analysis of this large collection of literature for the purpose of integrating the findings (Glass, 1976).

${ }^{2}$ Grey literature refers to research summaries, special publications, statistics, and other data that offer a more comprehensive view of a topic. Virtually everything outside of journals and books can be considered grey literature such as the internet, government publications, fact sheets, and statistical data. For a complete definition see Science \& Technology Section of Subject \& Bibliographic Access Committee (2003).

${ }^{3}$ Considering that there were a small number of studies that comprehensively and empirically examined youth pathways on PEI, we also sought more general studies of youth pathways (national and international).

${ }^{4}$ Interested readers should contact the first author for access to the ethical and research tools.

${ }^{5}$ All participants in this study have been given pseudonyms. 


\section{References}

Alvermann, D. E. (2009). Sociocultural constructions of adolescence and young people's literacies. In L. Christenbury, R. Bomer, \& P. Smagorinsky. (Eds.), Handbook of adolescent literacy research (pp. 14-28). New York, NY: Guilford Press.

Association of Canadian Community Colleges (ACCC). (2003). Essential employability skills: Case studies. Ottawa, ON: ACCC Secretariat.

Beaufort, A. (2009). Preparing adolescents for the literacy demands of the 21st century workplace. In L. Christenbury, R. Bomer, \& P. Smagorinsky. (Eds.), Handbook of adolescent literacy research (pp. 239-255). New York, NY: Guilford Press.

Beck, U. (1992). Risk society: Towards a new modernity. London, UK: Sage.

Bell, D., \& Bezanson, L. (2006). Career development services for Canadian youth: Access, adequacy and accountability. Ottawa, ON: Canadian Policy Research Network.

Bell, D., \& O'Reilly, E. (2008). Making bridges visible: An inventory of innovative, effective or promising Canadian school-to-work transition practices, programs and policies Executive summary. Ottawa, ON: The Work and Learning Knowledge Centre.

Berringer, R., Penner, A., \& Sutton, D. (2007). Admissions review year three: A joint project of adult and community education and holland college admissions. Charlottetown, PE: Holland College.

Bronfenbrenner, U. (1979). The ecology of human development: Experiments by nature and design. Cambridge, MA: Harvard University Press.

Canadian Rural Partnership. (2007). Youth speaks ... P.E.I. listens! Young leaders' forum 2007. Rural Dialogue Summary Report (Charlottetown, Prince Edward Island, Canada, March 9-10, 2007). Charlottetown, PEI: Author.

Carroll, W. (2009). Preliminary PEI labour force view. Charlottetown, PEI: University of Prince Edward Island.

Chaulk, P., McQuaid, S., \& Smith, N. (2002). An evaluation of the Employment Pathways Program: Final report. Charlottetown, PEI: Atlantic Evaluation Group.

Christenbury, L., Bomer, R., \& Smagorinsky, P. (Eds.). (2009). Handbook of adolescent literacy research. New York, NY: Guilford Press.

Eccles, J. S., Midgley, C., Wigfield, A., Buchanan, C. M., Reuman, D., Flanagan, C., \& MacIver, D. (1993). Development during adolescence: The impact of stage-environment fit on young adolescents' experiences in schools and in families. American Psychologist, 48(2), 90-101.

Elder, G. H., Jr. (1997). The life course and human development. In W. Damon \& R.M. Lerner (Eds.), Handbook of child psychology: Theoretical models of human development I (pp. 939-991). New York, NY: Wiley.

Elder, G. H., Jr. (1995). The life course paradigm: Social change and individual development. In P. Moen, G. H. Elder Jr., \& K. Lüsher (Eds.), Examining lives in context: Perspectives on the ecology of human development (pp. 101-139). Washington, DC: APA Press.

Evans, D. (2002). Database searches for qualitative research. Journal of the Medical Library Association, 90(3), 290-293.

Fine, M., \& Weis, L. (1996). Writing the "wrongs" of fieldwork: Confronting our own researchwriting dilemmas in urban ethnographies. Qualitative Inquiry, 2(3), 251-274.

Fitzgerald, M. D. (1998). To live and to learn: Homeless youth, literacy, education, and career. Halifax, Canada: Phoenix Youth Programs. 
Flanagan, K. (2009). Poverty reduction policies and programs: Prince Edward Island. Kanata, Canada: Canadian Council on Social Development.

Franke, S. (2010). Current realities and emerging issues facing youth in Canada: An analytical framework for public policy research, development and evaluation. Ottawa, Canada: Policy Research Initiative.

Freiler, C. (2010). Youth confidence in learning and the future: Position paper for discussion. Toronto, Canada: Canadian Education Association.

Furlong, A., \& Cartmel, F. (2007). Young people and social change: New perspectives. Buckingham, UK: Open University Press.

Furlong, A., Cartmel, F., Biggart, A., Sweeting, H., \& West, P. (2003). Youth transitions: Patterns of vulnerability and processes of social inclusion. Edinburgh, SCT: Scottish Executive Social Research.

Glass, G. V. (1976). Primary, secondary, and meta-analysis of research. Educational Researcher, 5(10), 3-8.

Hammersley, M., \& Atkinson, P. (1995). Ethnography: Principles in practice. London, UK: Routledge.

Knighton, T., Brochu, P., \& Gluszynski, T. (2010). Measuring up: Canadian results of the OECD PISA study. Ottawa, Canada: Industry Canada.

Lees, J.B. (2006). Literacy research in PEI: A reflection: Looking back before moving ahead. Charlottetown, Canada: PEI Literacy Alliance.

Lerner, R.M. (2006). Developmental science, developmental systems, and contemporary theories of human development. In W. Damon \& R.M. Lerner (Eds.), Handbook of child psychology: Volume 1, Theoretical models of human development (6th ed., pp. 1-17). New York, USA: John Wiley and Sons.

Lewis, C., \& Del Valle, A. (2009). Literacy and identity: Implications for research and practice. In Christenbury, L., Bomer, R., \& Smagorinsky, P. (Eds.), Handbook of adolescent literacy research (pp. 307-322). New York, NY: Guilford Press.

Lord, S. E., Eccles, J. S., \& McCarthy, K. A. (1994). Surviving the junior high school transition: Family processes and self-perceptions as protective and risk factors. The Journal of Early Adolescence, 14(2), 162-199.

Malcolmson, J. D. (2001). What works in youth literacy and why? A literature review and discussion. Vancouver, Canada: Youth Literacy Canada.

McKenna, G., \& Penner, A. (2009). Island prosperity report: Literacy levels in adult developmental education. Charlottetown, Canada: Holland College.

Morse, J. M. (2000). Determining sample size. Qualitative Health Research 10(1), 3-5.

Murphy, S. (2001). Backgrounder: Youth and work. Charlottetown, Canada: Institute of Island Studies, UPEI.

Organisation for Economic Cooperation and Development (OECD, 2010) PISA 2009 at a glance. OECD Publishing. Retrieved from http://dx.doi.org/10.1787/9789264095298-en

Paine, S. L., \& Schleicher, A. (2011). What the U.S. can learn from the world's most successful education reform efforts (Policy Paper). New York, USA: McGraw-Hill Research Foundation.

Pais, J. M. (2003). The multiple faces of the future in the labyrinth of life. Journal of Youth Studies 6(2), 115. 
PEI Advisory Council on the Status of Women. (2010). Considering the two-tier wage: Submission to the Standing Committee on Community and Intergovernmental Affairs Consultation on Different Minimum Wage Rates. Charlottetown, Canada: Author.

PEI Literacy Alliance. (2010). Environmental scan. Charlottetown, Canada: Author.

Silverman, D. (1993). Interpreting qualitative data: Methods for analyzing talk, text and interaction. London, UK: Sage.

Smith, D. (2002). Institutional ethnography. In T. May (Ed.). Qualitative research in action (pp. 17-52). London, UK: Sage.

Smith, D. (1990). The conceptual practices of power: A feminist sociology of knowledge. Toronto, ON: University of Toronto Press.

Smith, D. (1987). The everyday world as problematic: A feminist sociology. Toronto, ON: University of Toronto Press.

Smith, D. (1984). Textually mediated social organization. International Social Science Journal $36,59-75$.

Smyth, J., \& Hattam, R. (2001). 'Voiced' research as a sociology for understanding 'Dropping out' of school. British Journal of Sociology of Education, 22(3), 401-415.

Tilleczek, K. (2011) Approaching youth studies: Being, becoming, and belonging. Toronto, ON: Oxford University Press.

Tilleczek, K., \& Campbell, V. (2011) Youth pathways to literacy, education, and employment on Prince Edward Island. Charlottetown, PEI: University of Prince Edward Island Workplace Strategies Research Group.

Tilleczek, K., Laflamme, S., Ferguson, B., Roth Edney, D., Cudney, D., Girard, M., \& Cardoso, S. (March, 2010). Fresh starts and false starts: Young people in transitions from elementary to secondary school. Toronto, ON: Hospital for Sick Children.

Timmons, V. (2005). An extensive look at early school leavers on Prince Edward Island. Charlottetown, Canada: University of Prince Edward Island.

Unger, M. (2004). Nurturing hidden resilience in troubled youth. Toronto, Canada: University of Toronto Press.

Watt, D. (2002). Case study - Royal Star Foods Limited. Ottawa, Canada: The Conference Board of Canada.

Willms, J. D. (2009). Successful transitions: Findings from the National Longitudinal Survey of Children and Youth, Context paper presented at the Successful Transitions Conference, Human Resources and Skills Development Canada. Ottawa, April 28-29.

Willms, J. D. (1999). Quality and inequality in children's literacy: The effects of families, schools, and communities. In D. P. Keating \& C. Hertzman (Eds.). Developmental health and the wealth of nations. New York, USA: The Guildford Press.

\section{Author Biographies}

Kate Tilleczek is the Canada Research Chair in Youth Cultures and Transitions. She is also full Professor in Sociology/Anthropology and the Faculty of Education at the University of Prince Edward Island. She is the founder and Director of the UPEI Qualitative Research Lab and is also an Adjunct Research Scientist in the Learning Institute at The Hospital for Sick Children in Toronto, Canada. Dr. Tilleczek is engaged in three areas of research at present. 1) Engaging marginalized youth in public education, 2) the social and educational impacts of technology on young lives, 3) the barriers and facilitators to youth mental health. Her current funded projects 
relate to the impacts of the modern world (globalization and technology) on schools, young people and the mental health in Canada and beyond. For instance, Kate is leading a team on a CIDA project to build a school in southern Chile with and for indigenous youth and communities. She is also leading a SSHRC funded project on the impacts of technology on young lives over time and in place and another SSHRC-funded project to examine international innovations in research methods and theories about youth. She is leading another SSHRC-funded project to examine the best ways to engage the most marginalized youth back into public education. Kate is also currently working on a 5 year CIHR- funded project relating to the mental health of young people in Atlantic Canada. Her work reaches across sectors, disciplines and fields to attend to the well being of youth, families and communities. Her latest books are Youth Education and Marginality: Local and Global Expressions (WLU Press, 2013) and Approaching Youth Studies: Being, Becoming and Belonging (Oxford University Press, 2011).

Valerie Campbell is the Project Manager, Child/Youth Cultures and Transitions as well as a Sessional Lecturer in the Department of Sociology and Anthropology at the University of Prince Edward Island. She teaches Introductory Anthropology and gender-related courses, with a focus on Canadian issues. Valerie's research interests include gender and youth studies which she approaches with a holistic and comparative philosophy and a strong belief that research should be community driven and applied. 